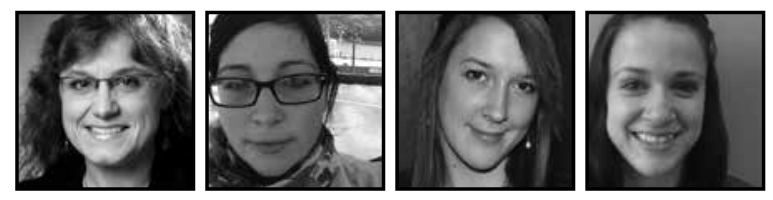

\title{
Twitter in a Bachelor of Education Course: Student Experiences
}

\author{
Jane P. Preston, Brittany A. E. Jakubiec, Julie Jones, and Rachel Earl,1 \\ University of Prince Edward Island
}

\section{ABSTRACT}

The purpose of this article is to describe student experiences when incorporating Twitter into a Bachelor of Education (BEd) course. Data for this participatory action research were gathered from eight first-year BEd students who provided written answers to 16 open-ended questions and participated in two focus group interviews. Findings indicated that, after participants completed a Twitter assignment, their views of Twitter and its applicability in educational realms changed. Analyzed through the emerging concept of new pedagogy, the Twitter experience enhanced collaboration and communication between student and the instructor. An implication is that if BEd students are to effectively incorporate technology into future kindergarten to grade 12 classrooms, they need to experience digital literacy during undergraduate courses.

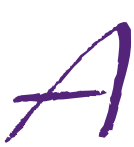

round the world, digital literacy is being threaded into educational curricula and learning outcomes (e.g., Hague \& Payton, 2010; International Society for Technology in Education, 2007). Even though teachers face intense pressure to promote student digital literacy, many kindergarten to postsecondary teachers lack formal training or background experience with regard to technology. Otherwise said, without the proper training, many teachers are expected to infuse e-learning, e-pedagogy, and technological tools into their lessons. Leonard and Leonard (2006) stated, "Technology integration remains problematic in that many teachers seem unwilling or unable to incorporate technology into the teaching and learning process" (p. 212). Furthermore, when teachers do incorporate technology into classroom 
environments, often the e-activities or technological practices are quite basic. For example, Creighton (2003) and Preston et al. (in press) found that most educators who incorporate technology into their teaching use basic tools like YouTube, multimedia presentations (e.g., PowerPoint), and class websites. Despite the need for teachers to integrate innovative technologies into kindergarten to postsecondary education, growth in this area is slow, challenging, and somewhat superficial (Abbitt, 2011; Bauer \& Kenton, 2005).

This study is founded on the belief that teachers need to be provided with ongoing professional development related to digital literacy and technological tools. With this assumption stated, the purpose of this article is to describe undergraduate student experiences when incorporating Twitter into a BEd course. Participants involved in this study were eight first-year Bachelor of Education students who helped analyze the data and are co-authors of this paper. Data were collected via one round of written responses to 16 open-ended questions and two focus group interviews. Findings showed that, after completing a Twitter assignment, participant views of Twitter and its applicability in educational realms changed. To analyze the findings, we unpack the concept of a "new pedagogy" (Fullan, 2013, p. 24).

\section{Literature Review: Twitter and a New Pedagogy}

The International Society for Technology in Education (2008) stated, "[Teachers should] model collaborative knowledge construction by engaging in learning with students, colleagues, and others in face-to-face and virtual environments" (para. 2). In response to this point, many authors contend that social media, such as Twitter, is a powerful environment to promote collaborative knowledge construction and socially enriched pedagogies (DeCosta, Clifton, \& Roen, 2010; Denton, 2012; Seo, 2013). Even though there is potential to foster high-level learning, Greenhow (2009) believed that one reason why Twitter and other social networking platforms are not widely integrated in kindergarten to postsecondary settings is the lack of social media experience of educators. That is, the teachers' readiness and willingness to learn about technology and social media directly affected their use, or lack thereof, of technology within the classroom (Inan \& Lowther, 2012; Rinaldo, Tapp, \& Laverie, 2011). O'Hanlon (2007) investigated the challenges of educators who were digital immigrants and not comfortable with social media platforms. O'Hanlon found that teacher anxiety around using social media in classroom settings dissipated once they actually used it. 
Specifically within the realm of higher education, Twitter has been slow to gain popularity (Kassens-Noor, 2010; Welch \& Bonnan-White, 2012). However, available research about Twitter in higher education shows favourable results, for the most part. Junco, Heiberger, and Loken (2011) found that Twitter engaged university students with course content, improved grades, provided students with prompt feedback, and increased student-to-student interaction. Other studies showed that Twitter was an ideal medium for enhancing a sense of class community and student engagement with course content (Dunlap \& Lowenthal, 2009; Evans, 2013; Junco, Elavsky, \& Heiberger, 2012). An additional benefit of Twitter in higher education is that it increased communication between students and the instructor, because Twitter enabled students to post questions and comments during and after class (Junco et al., 2011; Tyma, 2011). Young (2009) found that Twitter dissipated power dynamics between instructor and students, enabling the student to be in more control of learning. Through Twitter, students are able to express their ideas through their personal tweets and are empowered to consider and respond to other students' tweeted thoughts. Miners (2009) indicated that some college professors display Twitter feeds on a dedicated classroom screen as a way to embellish interaction with students in large or lecture-style classrooms. In turn, these studies documented that the use of Twitter in higher education increased student motivation to learn, increased one-task engagement among students, and improved the relationships between students and with the instructor.

With these benefits articulated, a few studies contradict the above findings. Welch and Bonnan-White (2012) concluded that Twitter did not have a statistically significant effect on student engagement in a higher education setting. Other studies point out that some postsecondary students do not like using Twitter, because they prefer to keep their personal social media activities separate from academic realms of communication (Dahlstrom, Walker, \& Dziuban, 2013; Haytko \& Parker, 2012). It appears that the advantage of using Twitter in higher education may depend on the course content, the assignment task, and the instructor and students' expectations for Twitter.

With or without Twitter, for most students, their world is a digital one. Through use of an array of digital devices, students are accustomed to instant and consistent interaction with family and friends. For some students, the thought of being socially disconnected from family and peer groups is almost unthinkable (Gillett, 2015). When instructing this Net Generation (i.e., a person who grew up witnessing the genesis and/or proliferation of the Internet), teachers have a new responsibility to incorporate digital learning and technological devices into their courses. When reflecting upon this new role, the most important change is not related to technology, per se. Rather, the change is conceptual 
in nature (Prensky, 2012). In the past, within most classroom settings, teachers were the dominant leaders, while students were to be passive learners, obedient followers, and recipients of content. Within a technologically vibrant classroom, teachers are no longer caretakers of stagnant knowledge. As well, Fullan $(2013,2014)$ and Hattie (2012) believed that teachers need to be more than facilitators. They need to be activators or generators of constructive learning experiences for students. The re-examination of the teacher's role represents new relationships that need to emerge between, and among, teacher and students. These new relationships foster a type of learning that is decentralized, non-hierarchical, social, hyper-linked, collaborative, and symbiotic. These relationships spotlight a new role for students, as well, one that endorses the student as tutor, coach, and teacher of other students (and even the teacher). Moreover, this new pedagogy happens in an environment where technology is ubiquitous (Fullan, 2013). In sum, the concept of new pedagogy refers to the teacher as learning activator. It also means students dynamically assuming the responsibility of knowledge activator, producer, and disseminator (Fullan, 2013, 2014; Prensky, 2012; November, 2010, 2012).

\section{Research Design: Participatory Action Research}

In many qualitative research designs (e.g., case studies, phenomenology, etc.), the researcher is often the authority figure, responsible for collecting, interpreting, and analyzing the findings. Meanwhile, the participants of the study merely represent the voice of people or the case being investigated. In contrast, participatory action research, the chosen qualitative research approach used for this study, validates and honors the experiences of participants, making them the co-authority, co-researchers, and collaborators during the planning of the study, gathering of data, analysis of data, and write-up of the final results (Chevalier \& Buckles, 2013). Kemmis and McTaggart (2005) described participatory action research as a social process where co-learning, experienced by a group of people, is meant to improve professional practice and/or societal issues. The process engages the researchers (who are also the participants) in examining their knowledge, understanding, abilities, and beliefs about the pertinent topic. By its very name, participatory action research is participatory.

There are many reasons why participatory action research was conducive in the planning, conducting, and analysis of this study. To begin, the first author of this paper was the instructor of the undergraduate course referred to in this research, and the co-authors of this paper were both students in her course and participants/ co-researchers for this research. Some scholars may view addressing research in such a 
fashion as highly subjective. Not only do we agree with this statement, but we also see great value in such subjectivity. We believe that the findings articulated herein have as much merit (maybe even more) than more traditional ways of conducting qualitative results. For example, all researchers for this study used their personal knowledge, senses, emotions, and intuition to understand the nuances and meaning embedded in the shared data. In turn, all raw data and its representation (e.g., transcripts, analysis, and write-up) have been thoroughly member checked (Stake, 2010) by participants/ co-researchers. Not only did participants review their transcripts, but participants also assisted in the analysis and write-up of the data. By having the authors create and own the findings, a credible representation of results emerges.

\section{Research Background}

At the time of the study, all participants possessed an undergraduate degree, predominantly a Bachelor of Arts with various specializations. With this degree, participants enrolled into the University of Prince Edward Island, Bachelor of Education program. As a part of the BEd program, all students, including the eight BEd participants of this study, were mandated to take a course entitled, Communications. The content for the Communications course involved the introduction of basic educational topics, such as gaining familiarity with provincial curricula, lesson plans, unit plans, student assessment techniques, classroom management strategies, and teacher-parent collaboration in school. The same course was offered during two timeframes (or two sections); each section had enrollments of 25 and 26 students. For this pass-fail course, the instructor asked the students to complete five assignments, one of which was based on Twitter, an assignment where every student was asked to tweet at least three times per week throughout the nine-week course. The content of the tweets was to reflect the students' learning, ideas, and/or questions relating to each week's course content. (See the Appendix for the Twitter assignment that was given to the students.)

After the course was completed, the instructor invited all 51 students to articulate their views and co-write an article based on their Twitter experiences. Eight students volunteered to participate. Data reflected written answers to a set of 16 open-ended questions, an activity that students completed six weeks after completing the course. Data also included two focus group interviews (Krueger \& Casey, 2009; Puchta \& Potter, 2004) conducted two months and one year after completing the course. The focus group interviews were transcribed by a few of the students. All students were provided with a written copy of focus group interview transcripts and were asked to member check 
the transcripts. In analyzing data, we reviewed the written answers and the focus group transcripts to create a preliminary list of key ideas, commonalities, and differences, which converged into larger thematic patterns in response to the study's purpose (Creswell, 2012).

\section{Data Findings}

When first introduced to the assignment, most participants were hesitant. However, not only did their attitude toward the assignment change, but they also articulated many of the benefits they experienced due to Twitter. These benefits included feeling engaged with course content, developing a digital identity, and increasing their digital literacy. Participants also articulated several challenges pertaining to the Twitter assignment and the applicability of this social media tool in a kindergarten to grade 12 setting. These challenges include the 140-character limit and questions pertaining to age-appropriate use of Twitter. Descriptions of these thematic findings are explicated below.

\section{Initial Attitude: Doubtful and Hesitant}

Upon being introduced to the course syllabus and the Twitter assignment, the majority of participants were either hesitant or skeptical about the merits of the Twitter, specifically in a BEd program. For example, Robyn explained, "I thought the [Twitter] assignment was a complete waste of time." Other comments included "My initial reaction to the Twitter assignment was curiosity, and, I will admit, a bit of skepticism" (Brittany). "As I read the criteria for the assignment, I felt more and more nervous about having to tweet, having to set up tweet deck, and having to tweet 3 to 4 times a week. I was dreading it." (Angela). "I was sceptical about its potential for pedagogical use" (Joseph). "Although I felt quite confident in my abilities due to my prior experience with Twitter, I was unsure of how any assignment could be adequately completed in 140 character limits" (Rachel). "I was concerned that I would have problems setting up my account and to begin the process of tweeting. I was also concerned about things such as privacy while using a Twitter account" (Shannon). Robyn also explained that most of her classmates were at least somewhat resistant to the idea of the Twitter assignment. She said, "Almost everyone I talked to did not think that such an assignment fit into what they believed we should be learning in the Education program." Although the majority of comments mirrored a theme of reluctance or hesitancy about Twitter, Julie and Kaitlyn provided some contrasting points. "I felt somewhat excited, because 
I would be able to use my [pre-established] Twitter account for something educational" (Julie). "I saw it as an easy way to boost our grades" (Kaitlyn). In sum, upon hearing that one of their BEd assignments was to regularly tweet about their learning, most participants were doubtful of its educational value.

\section{Benefits: Engagement, Rapport, Communication, Assessment, and Digital Comfort}

After completing the Twitter assignment, the views of most participants changed. Their comments represented several thematic benefits, one of which was student engagement. Kaitlyn explained, "Often times I would not really feel like doing the assigned readings for the week, but some of the interesting tweets about the content would spark my curiosity and make me more inclined to actually do the readings." Robyn said:

The [Twitter] assignment helped to keep me engaged with the course material ... Reading other people's tweets also helped me to pick out the key points from the week or helped draw my attention to something in the book that I hadn't paid much attention to.

Robyn also pointed out, "The assignment became so engaging and interesting that some of the tweets even became topics of discussion between classmates outside of class." Rachel explained how tweeting made her more engaged with course content when she said:

When I would think of a topic to tweet about, whether it was concerning an assigned reading or an activity, which we had completed in the classroom, I had to think very deeply about what it is that I had taken away from that experience.

Brittany's comments summed up student engagement when she said, "Using Twitter ... provides students with the opportunity to be active in their learning, as they are creating and expressing the content [of their learning.]"

Another thematic benefit that surfaced was an increased feeling of classroom community. In particular, this enriched sense of rapport was because Twitter increased the communication and sharing of ideas among students. Julie explained that tweeting was an easy and convenient way to collaborate with other students, without having physically to meet outside of class time. Kaitlyn believed that the content of her classmates' tweets revealed the personalities of individual students and the class, 
as a whole. In turn, she indicated, "It was a useful way to get to know our classmates." Robyn's comment relayed a similar meaning: "It's a great way to know someone's personality, interests, and values." Rachel, Angela, and Brittany explained how student voice and ideas were communicated via Twitter. "It is such a simple and effective way to share ideas with others" (Rachel). "I absolutely loved how Twitter allowed me to view my peers' thoughts, ideas, and opinions" (Angela) "[Twitter enabled] students to work collaboratively with their classmates, building a community that supports a great learning environment" (Brittany). Angela and Rachel also highlighted that, in particular, Twitter was an effective outlet for students who were naturally shy or introverted during class time. These students could articulate their thoughts and ideas to peers in a comfortable fashion. Robyn's comments summed up the theme of community when she said:

The interactive nature of Twitter has great potential for improving feelings of inclusiveness and community in the classroom ... It also helped improve classroom rapport as there was a constant discussion occurring between all students in the class.

According to the participants, another benefit of the Twitter experience was that it improved communication between the instructor and students. Shannon found that tweeting was "a simple process that I could use to communicate quickly and efficiently with my peers and instructors." Shannon said, "It allows the professor to see what each student is learning and thinking about the class ... it's also a very advantageous form of communication between professor and student." Julie believed that Twitter was a way "our professor could tell if we were doing our weekly readings or not." On the topic of assessment, Robyn articulated her belief that "It is a great form of formative assessment for the teacher, as they are able to see what the students are having difficulties with, what they understand, and what they like or dislike about the subject material, or lessons."

Another thematic benefit of the Twitter assignment was that the experiential learning of tweeting was a catalyst for improving the digital confidence of participants. Prior to the course, Shannon had no contact with Twitter, and, for her, the main advantage of the Twitter assignment was the actual experience of tweeting and experiencing Twitter. In turn, she said, "I think that's one really important aspect of this Twitter assignment-to alleviate the anxiety of working with new technology ... I gained a lot more confidence in my ability to use these tools and programs." Rachel believed that tweeting in an undergraduate course "expressed ways of thinking about Twitter in an educational context." Kaitlyn had never used Twitter before, and she was thankful that she now had comprehensive experience of what Twitter encompassed. 
Brittany confessed that, before the assignment, she had heard about hashtags, but was not clear on their meaning. She continued by explaining, "Prior to the assignment, I had no idea of how to really use or talk about Twitter." Likewise, Robyn said, "I feel the same. I had never used it before the class, and I had no clue what it meant to follow someone, choose to follow someone, or what hashtags could do. No clue." Angela provided a short narrative about how the Twitter experience helped her during her teaching practicum. She said:

I had a kid in Grade 1 in my practicum who asked me if he was allowed to go on his Twitter account. He's 6 years old, and he is asking me about that. I could have a conversation with him about Twitter, because I now understand what Twitter is about.

For many participants, the hands-on experience of tweeting was like an epiphany, because, through the hands-on experience of Twitter, students began understand the need to become more technologically literate and the related benefits.

\section{Challenges: Characters and Age Appropriateness}

There were several challenges attached to completing the Twitter assignment. One frustration that some participants experienced pertained to Twitter's 140-character limit. Kaitlyn and Joseph found that the most difficult aspect of the assignment was compressing their thoughts into 140 characters. Shannon also found that the limit in characters prevented her from providing details or being descriptive about a special topic. On the other hand, Angela and Rachel found the 140-character limit to be advantageous, because it forced them to be succinct and to the point. Robyn found the 140-character limit to be inspirational, because "I started trying to think creatively about what I could tweet in 140 characters or less, and, all of the sudden, the assignment became quite enjoyable."

Issues of privacy and the potential content of tweets were two additional concerns expressed by participants. Participants envisioned these concerns as especially pertinent for younger students who might not fully understand how Twitter works. Rachel explained, "My major concern with introducing Twitter to a classroom would be the age range of the students involved. Younger students may not have the emotional maturity required to responsibly run a social media platform." Brittany agreed that it would be difficult to monitor the online behavior of all students. Robyn worried about 
the teacher not having the ability to delete or regulate the students' tweets, and she questioned, "What if they tweet inappropriate things? What would happen to the feelings of the students in the rest of the class?" Julie viewed Twitter, in a university setting to be beneficial for learning, but within a public school setting, Julie believed that before using Twitter, issues around privacy must be taught to the students. Additional participants had concerns about privacy. Shannon confessed that she did not fully understand Twitter's privacy issues, herself. Rachel discussed the dilemma of teaching curriculum content and digital literacy with limited class time available. On this topic she said, "How do you weigh the importance of giving students technological tools versus 'I only have so much time to teach them actual course content?'" An interesting aspect of this finding was that the participants' Twitter exchanges provided them with hands-on social media experience, which was fundamental to being fully engaged in discussions about Twitter and its benefits and challenges.

\section{Discussion: New Pedagogy}

Postsecondary instructors are teaching the most techno-social generation of students in history. It is understandable that teachers may feel overwhelmed in attempting to incorporate technology into their classroom settings. Having stated such, it was interesting that some of the students in this study became anxious about the Twitter assignment and that most of the students had never used Twitter or had limited experience with it. This finding showed that, although instructors might potentially feel intimidated by the technological experience they assume their students have, this assumption may be false. When applying this point to BEd programs, it cannot be assumed that BEd students know how to incorporate technology into their pedagogy. Pre-service teachers need to gain technological experience, confidence, and skills during their undergraduate courses so they can effectively incorporate technology into future kindergarten to grade 12 classrooms.

Another finding was that the Twitter experience embellished the students' digital identity. At the start of the course, participants were skeptical about the merits of the Twitter assignment, but after experiencing this digital platform, they possessed increased confidence and comfort with the tool. Possessing this digital comfort enabled students to envision the benefits and challenges of using technology with their future students. Hosted through new pedagogy, it was the constructive learning experience that was effective in transforming the students' digital identity and views about Twitter. 
Through Twitter, students used their own-and each other's tweets-to positively influence student engagement, classroom rapport, and student-student and student-instructor communication. This type of social learning welcomed all learner personalities to share their thoughts. For example, through Twitter's online communicative platform, students who were, by nature, extroverts or introverts, became equal. Prensky (2012) believed that a core purpose of new pedagogy is to use technology to enhance all types of relationships, whether they are face to face or online.

Incorporating Twitter into the postsecondary course was a break from the traditional learning activities. New pedagogy is altering traditional patterns of how and where information is acquired, stored, interpreted, and disseminated. New pedagogy is about transforming how educators and students are influenced by each other's ideas. For example, the collection of tweets reflected the group's co-created knowledge and where hierarchical levels of knowledge creation were alleviated. In such a manner, via new pedagogy, teachers and students move between being leaders and followers, a term sometimes referred to as reciprocal mentors (Gabriel \& Kaufield, 2008).

Somewhat attached to the above point, new pedagogy is also related to the idea of reverse mentorship (November, 2012). Because most educators currently represent digital immigrants (i.e., people who did not grow up with technology), it is imperative that these educators call upon the leadership and knowledge of the Net Generation. Levinson (2010) explained that adults tend to view technology as a source of information, while students view technology as a way of life, as entertainment or a socializing tool. For the most part, students are open to technology. Teachers need to be open to the technological demeanor of their students (November, 2010). The idea of reverse mentorship is aligned with concepts of new pedagogy, where learning is non-hierarchical and a shared process and product. Within this research, although many students were somewhat anxious, at first, to complete the Twitter assignment, once they started, their anxiety quickly dissipated. It is during this stage of anticipation that reverse mentorship can thrive.

Another final aspect of new pedagogy is exemplified in the research design chosen for this study. Fullan (2013) depicted new pedagogy as teacher and students being learning partners. Participatory action research is about full partnerships during the creation, organization, and dissemination of research. New pedagogy is about students being proactive in learning. Within this study, participants were volunteers and co-creators of the research. Every participant contributed to the literature review, several students completed the interview transcripts, and every student contributed to this article. Moreover, almost every step of the research involved the use of Google Drive, 
cloud-based software and storage systems that offered an online learning environment for synchronous and asynchronous interaction between all writers. In these ways, participatory action research exemplifies characteristics of new pedagogy.

\section{Conclusion}

Kelly, McCain, and Jukes (2012) indicated that many teachers are still presenting curricular content as it was taught during the Industrial Age. A daunting question facing many educators today is how to best serve the masses of postsecondary students who want training that is applicable to their life aspirations and that provides the skills needed to thrive in a digital world (Gillett, 2015). If higher education is to successfully prepare students for the future, then student-centered, hands-on, digital learning is part of the answer. Postsecondary instructors need to embody a type of pedagogy that focuses on real-life problem solving and knowledge creation with the assistance of technology. Becoming comfortable with using technology within postsecondary courses has great potential to grow a digital career-related identity, as opposed to a digital identity for social purposes. When teacher-to-student and student-to-student groups share their technical knowledge, there is great potential to promote the students' digital career-related identity. Postsecondary classrooms are readily equipped, via student knowledge, with a digital culture that is organic and current. However, this digital culture remains dormant until instructors, through employing new pedagogy, become the change agent tapping into and extending the digital abilities of students.

Interestingly, when conducting a literature review on Twitter (one of the most popular forms of social media), few studies surfaced. An implication evolving from this study is that additional research needs to be undertaken to explore the benefits and challenges of Twitter and how it can be linked to enriched student learning. Also, new pedagogy is a new concept, which needs be further investigated and refined. What supports to educators need to embody a new pedagogy? Through addressing such questions, the coevolution of technology and learning will be better understood, therein supporting teachers as they embrace the power of the digital age. 


\section{Note}

1. The authors would like to thank Robyn Christensen, Shannon Kemp, Joseph N. Lillo, Kaitlyn MacKenzie, and Angela DesRoches for their invaluable contributions to the participatory action research.

\section{References}

Abbitt, J. T. (2011). An investigation of the relationship between self-efficacy beliefs about technology integration and technological pedagogical content knowledge (TPACK) among preservice teachers. Journal of Digital Learning in Teacher Education, 27(4), 134-143.

Bauer, J., \& Kenton, J. (2005). Toward technology integration in the schools: Why it isn't happening. Journal of Technology and Teacher Education, 13(4), 519-546.

Chevalier, J. M., \& Buckles, D. J. (2013). Participatory action research: Theory and methods for engaged inquiry. New York: Routledge.

Creighton, T. (2003). The principal as technology leader. Thousand Oaks, CA: Corwin Press.

Creswell, J. W. (2012). Qualitative inquiry and research design: Choosing among five approaches (3rd ed.). Thousand Oaks, CA: Sage.

Dahlstrom, E., Walker, J. D., \& Dziuban, C. (2013). ECAR study of undergraduate students and information technology, 2013. Louisville, CO: Educause Center for Analysis and Research. Retrieved from: http://net.educause.edu/ir/ library/pdf/ERS1302/ERS1302.pdf

DeCosta, M., Clifton, J., \& Roen, D. (2010). Collaboration and social interaction in English classrooms. English Journal, 99(5), 14-21.

Denton, D. W. (2012). Enhancing instruction through constructivism, cooperative learning, and cloud computing. TechTrends, 56(4), 34-41.
Dunlap, J. C., \& Lowenthal, P. R. (2009). Horton hears a tweet. EDUCAUSE Quarterly, 32(4), 1-11.

Evans, C. (2013). Twitter for teaching: Can social media be used to enhance the process of learning? British Journal of Educational Technology, 1-14. doi:10.1111/bjet.12099

Gabriel, M. A., \& Kaufield, K. J. (2008). Reciprocal mentorship: An effective support for online instructors. Mentoring \& Tutoring: Partnership in Learning, 16(3), 311-327.

Gillett, B. (2015, April 29). Education in a digital age. Academia. Retrieved from: http:// forum.academica.ca/articles/2015/4/29/ written-by-bob-gillett

Greenhow, G. (2009). Social scholarship: Applying social networking technologies to research practices. Knowledge Quest, 37(4), 42-47.

Fullan, M. (2013). The new pedagogy: Students and teachers as learning partners. LEARNing Landscapes, 6(2), 23-29.

Fullan, M. (2014). Stratosphere: Integrating technology, pedagogy, and change knowledge. Toronto, ON: Pearson.

Hague, C., \& Payton, S. (2010, November). Digital literacy across the curriculum: A Futurelab handbook. Retrieved from: http://www2. futurelab.org.uk/resources/documents/ handbooks/digital_literacy.pdf

Hattie, J. (2012). Visible learning for teachers. London, England: Routledge. 
Haytko, D. L., \& Parker, R. S. (2012). Social networking tools in a university setting: A student's perspective. Journal of Instructional Pedagogies, 9(1), 1-9.

Inan, F., \& Lowther, D. (2010). Factors affecting technology integration in K-12 classrooms: A path model. Educational Technology Research \& Development, 58(2), 137-154. doi:10.1007/s11423-009-9132-y.

International Society for Technology in Education. (2007). NETS for students 2007. Retrieved from: http://www.iste. org/standards/standards-for-students/ nets-student-standards-2007

International Society for Technology in Education. (2008). The ISTE National Educational Technology Standards (NETS.T) and performance indicators for teachers. Retrieved from: http://images.apple.com/jp/ education/docs/Apple-ISTE-NETS-Teachers. pdf

Junco, R., Elavsky, C. M., \& Heiberger, G. (2012). Putting Twitter to the test: Assessment outcomes for student collaboration, engagement and success. British Journal of Educational Technology, 44(2), 272-287. dio:10.1111/j.1467-8535.2012.01284.x

Junco, R., Heiberger, G., \& Loken, E. (2011). The effect of Twitter on college student engagement and grades. Journal of Computer Assisted Learning, 27(2), 119-132. doi:10.1111/j.1365-2729.2010.00387.x

Kassens-Noor, E. (2012). Twitter as a teaching practice to enhance active and informal learning in higher education: The case of sustainable tweet. Active Learning in Higher Education, 13(1), 9-21. doi:10.1177/1469787411429190

Kelly, F. S., McCain, T., \& Jukes, I. (2012). No more cookie-cutter high schools. In L. Schrum (Ed.). Educational technology for school leaders (pp. 25-40). Thousand Oaks, CA: Corwin.

Kemmis, S., \& McTaggart, R. (2005). Participatory action research: Communicative action and the public sphere. In N. K. Denzin \& Y. S. Lincoln (Eds.). The Sage handbook of qualitative research (3rd ed., 559-603). Thousand Oaks, CA: Sage.
Krueger, R. A., \& Casey, M. A. (2009). Focus groups: A practical guide for applied research (4th ed.). Thousand Oaks, CA: Sage.

Leonard, L. J., \& Leonard, P. E. (2006). Leadership for technological integration: Computing the reality. Alberta Journal of Educational Research, 54(2), 212-224.

Levinson, M. (2010). From fear to Facebook: One school's journey. Washington, DC: International Society for Technology in Education.

Miners, Z. (2009). Twitter takes a trip to college. U.S. News \& World Report, 146(8), 56-57.

November, A. (2010). Empowering students with technology (2nd ed.). Thousand Oaks, CA: Sage.

November, A. (2012). Emerging roles within the knowledge community. In L. Schrum (Ed.). Educational technology for school leaders (pp. 59-76). Thousand Oaks, CA: Corwin.

O'Hanlon, C. (2007). If you can't beat'em, join'em. T.H.E. Journal, 34(8), 38-42.

Prensky, M. (2012). Partnering: A pedagogy for new educational landscape. In L. Schrum (Ed.). Educational technology for school leaders (pp. 3-23). Thousand Oaks, CA: Corwin.

Preston, J. P., Moffatt, L., Wiebe, S., McAuley, S., Campbell, B., \& Gabriel, M. (in press). The use of technology in Prince Edward Island (Canada) high schools: Perceptions of educational leaders. Educational Management Administration \& Leadership, 43(3).

Puchta, C., \& Potter, J. (2004). Focus group practice. London, UK: Sage.

Rinaldo, S.B., Tapp, S., \& Laverie, D.A. (2011). Learning by tweeting: using Twitter as a pedagogical tool. Journal of Marketing Education, 33(2), 193-203. doi:10.1177/0273 475311410852

Seo, K. K. (Ed.). (2013). Using social media effectively in the classroom: Blogs, wikis, Twitter, and more. New York: Routledge.

Stake, R. E. (2010). Qualitative research: Studying how things work. New York: The Guildford Press. 
Tyma, A. (2011). Connecting with what is out there!: Using twitter in the large lecture. Communication Teacher, 25(3), 175-181. doi:10.1080/17404622.2011.579911

Welch, B. K., \& Bonnan-White, J. (2012). Twitter to increase student engagement in the university classroom. Knowledge Management \& E-Learning: An International Journal, 4(3), 325-345.
Young, J. R. (2009, November 22). Teaching with Twitter: Not for the faint of heart. The Chronicle of Higher Education. Retrieved from: http://chronicle.com/article/TeachingWith-Twitter-Not-for/49230/

\section{Appendix: ED473 Communications Twitter Assignment}

A. Due Date: Throughout the course. You must tweet at least 3 to 4 times every week of class. (One tweet a day would be great!) Final tweets are due by Friday, November 16, 2012 by 11:59 pm (for Sec G \& J)

B. Twitter Background: Launched in 2006, Twitter is an online application that is a quasi-blog, quasi-social networking tool, and quasi-texting tool. It is designed to let other tweeters know what you are doing and thinking. Users have up to 140 characters (which includes spaces and hash tag addresses) to articulate their thoughts or "tweets." Through Twitter, users can follow the thoughts and activities of people they know and people they don't know.

C. Why Tweet In ED473? Tweets are meant to enhance the active learning, collective learning, and selfreflective practices of ED473 students.

D. Twitter Expectation: Students are expected to:

1. Tweet 3 to 4 times for every week of the course (that's once every day or two). The last day you can tweet is Friday, November 16, 2012 (by 11:59 pm). Because the course runs 9 weeks, you must have tweeted at least $\mathbf{3 6}$ times by the end of the course. You cannot tweet 36 times on the night of November 16th. Can you create multiple tweets in one sitting? Yes, but then tweet 2 or 3 again that week during different sittings.

2. Use professional/respectful tweets to communicate your learning, questions, and any other comments pertaining to course content, classroom activities, information from the textbook, articles for the course, handouts for the course, homework activities, etc.

3. Use tweets as a self-reflective, metacognitive activity to enhance personal and collective student learning. (Metacognition is the practice of thinking/reflecting about one's own learning in an effort to improve comprehension and retention of information.)

4. Use tweets to analyze course content. More specifically, tweet about your learnings, questions, and any other comments you might have regarding ED473 content and experiences.

5. Improve communication skills by clearly and succinctly articulating ideas through a 140-character tweet. (Being brief and to the point is an important part of communication.)

6. Tweet ideas using course section hash tag. That is, ED473G students are responsible for tweeting using \#ed473g, and ED473J students are responsible for tweeting using \#ed473j. I will only assess tweets students have created within their own sections. By all means, tweet across sections, but I will not assess cross-section tweets. 


\section{E. Set Up a Twitter Account (if you don't have one)}

1. If you haven't already, set up a Twitter account (twitter.com)

2. If desired, personalize your profile page and decide on settings

3. Click. Write your tweet.

F. Setting Up TweetDeck Account for \#ed473g \& \#ed473j Set up a TweetDeck account, so that your section's tweets are in one place or column. To create TweetDeck account:

1. Type www.tweetdeck.com in a search browser

2. Click "create account"

3. Enter e-mail and password, click "sign up"

4. Click "add Twitter account"

5. Enter Twitter username and password; click "Authorize app" and close window

Go back to TweetDeck. Set up one column in your TweetDeck just for your ED473 class/section. To do so:

1. Click "add column" (top left corner)

2. Click "search"

3. Enter hashtag (e.g., \#ed473g); hit "enter"

4. Highlight search and click "add column"

5. Repeat the above steps to create a column for \#ed473j

6. Go back to Twitter account and start tweeting

\section{G. Remember ...}

- As a teacher, you are a professional. Everything you tweet represents both you and the teaching profession.

- All tweets are public and permanent. Any and all future employers will be able to potentially find and read your tweets.

- Each tweet identifies the tweeter (that's you), your screen name, \& links to your profile and all previous tweets.

- Be considerate and respectful in all tweets.

- Tweets can include spelling abbreviations (e.g., " $4 \mathrm{U}$ " [for you]).

\section{H. Instructor Assessment for Twitter Assignment}

\begin{tabular}{|l|l|l|}
\hline \multirow{2}{*}{ \# of tweets } & Needs Improvem't/Fail & Great/Pass \\
\hline \multirow{2}{*}{$\begin{array}{l}\text { Quality } \\
\text { of tweets }\end{array}$} & $\begin{array}{l}\text { 0 to 2 tweets per week (or a total of 0 to 35 } \\
\text { tweets during the course) }\end{array}$ & $\begin{array}{l}\text { 3 or more tweets per week (that's 36 or more } \\
\text { tweets during the course }\end{array}$ \\
\cline { 2 - 3 } & $\begin{array}{l}\text { The 0 to 2 tweets per week were done in one } \\
\text { sitting. }\end{array}$ & $\begin{array}{l}\text { 3or more tweets per week were done in } \\
\text { different sittings. }\end{array}$ \\
\hline & $\begin{array}{l}\text { Tweets did not reference or relate to a variety } \\
\text { of information from the course textbook, } \\
\text { articles, handouts, homework activities, and/ } \\
\text { or activities related to ED473 }\end{array}$ & $\begin{array}{l}\text { Tweets referred or related to various } \\
\text { information from the course textbook, } \\
\text { articles, handouts, homework activities, and/ } \\
\text { or activities related to ED473 }\end{array}$ \\
\cline { 2 - 3 } & $\begin{array}{l}\text { Tweets displayed little to no self-reflection } \\
\text { of course content and/or activities related } \\
\text { to ED473 }\end{array}$ & $\begin{array}{l}\text { Tweets displayed self-reflection of course } \\
\text { content and/or activities related to ED473 }\end{array}$ \\
\cline { 2 - 3 } & $\begin{array}{l}\text { Tweets displayed little to no analysis of } \\
\text { content and/or activities related to ED473 }\end{array}$ & $\begin{array}{l}\text { Tweets displayed analysis of content and/or } \\
\text { activities related to ED473 }\end{array}$ \\
\hline Professionalism & $\begin{array}{l}\text { Most tweets were professional and respectful } \\
\text { in nature }\end{array}$ & $\begin{array}{l}\text { All tweets were professional and respectful } \\
\text { in nature }\end{array}$ \\
\hline
\end{tabular}




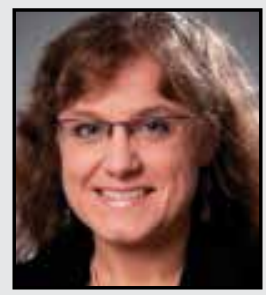

Jane P. Preston is an Assistant Professor at the University of Prince Edward Island, where she is the Academic Lead for the Certificate in Leadership Education in Nunavut program. Her core research interests include leadership issues, technology in Kindergarten to postsecondary settings, rural education, and Aboriginal issues. Jane's research interests stem from 10 years of K-12 teaching in Canada, Taiwan, Egypt, and Kuwait.

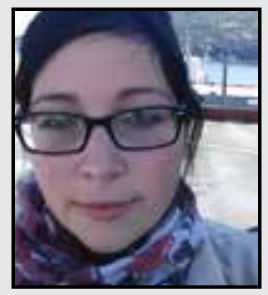

Brittany A. E. Jakubiec is a PhD in Educational Studies student at the University of Prince Edward Island. Her main areas of interest in higher education are women's issues, leadership, and transformative learning. Personal areas of interest include spending time with family, reading, traveling, and playing board games.

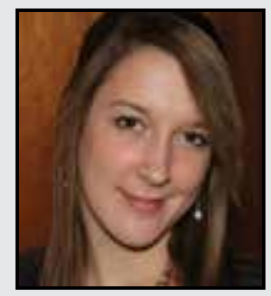

Julie Jones is a recent Bachelor of Education graduate from the University of Prince Edward Island. Her undergraduate degree consisted of an English major and History minor. Among her core interest in teaching the junior high and high school level, Julie also specialized in Indigenous Education. Aside from teaching, Julie's personal interests consist of spending time with loved ones, reading, traveling, snowboarding, and riding her motorcycle.

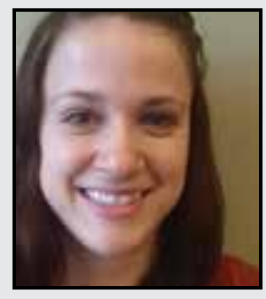

Rachel Earl is an education enthusiast based out of Charlottetown, Prince Edward Island. She holds a Bachelor of Arts as well as a Bachelor of Education (intermediate level) from the University of Prince Edward Island. She is currently employed in the public sector as a youth employment program coordinator. Her hobbies include knitting, biking, and youth engagement. 